\title{
Multiple Scale Den Site Selection by Swift Foxes, Vulpes velox, in Southeastern Colorado
}

\author{
AnN M. Kitchen ${ }^{1}$, ERIC M. GeSE ${ }^{2}$, and SARAH G. LuPis ${ }^{1}$ \\ ${ }^{1}$ Department of Forest, Range and Wildlife Sciences, Utah State University, Logan, Utah 84322-5230 USA. Present address: \\ National Zoological Park, Smithsonian Institution, Washington DC 20013-7012 USA. Corresponding author: Henderson \\ An@si.edu \\ ${ }^{2}$ U.S. Department of Agriculture, Wildlife Services, National Wildlife Research Center, Department of Forest, Range and \\ Wildlife Sciences, Utah State University, Logan, Utah 84322-5230 USA.
}

Kitchen, Ann M., Eric M. Gese, and Sarah G. Lupis. 2006. Multiple scale den site selection by Swift Foxes, Vulpes velox, in southeastern Colorado. Canadian Field Naturalist 120(1): 31-38.

Predation by Coyotes (Canis latrans) is a major source of mortality in Swift Fox (Vulpes velox) populations. Year-round den use by Swift Foxes is likely to be a predator avoidance strategy. Due to the importance of denning to Swift Fox ecology, we recorded den site selection of Swift Foxes in southeastern Colorado. Den site selection was recorded at two scales: microhabitat characteristics at the den and den placement within the home range. The number of den entrances, height and width of each entrance, aspect, hill position, slope, percent rock in soil, vegetative cover, and horizontal foliar density of 42 Swift Fox dens were examined during December 1999 - April 2000. This was compared to the same microhabitat characteristics at 42 random sites within Swift Fox home ranges to determine if Swift Foxes were using site characteristics according to their availability. Our results indicated that Swift Foxes were not highly selective of den sites based on the microhabitat characteristics evaluated in this study, although Swift Foxes selected areas of intermediate rock percentages. In addition, Swift Foxes were radio-tracked throughout the sample period and the location and frequency of use of known dens were recorded. Within the core area of home ranges, Swift Foxes used more dens (mean $=3.51 \pm 1.70$ (SD)), and had a higher frequency of use of dens (mean $=8.20 \pm 6.01$ ) than in the mid-range area (number of dens, mean $=0.90 \pm 0.94$; frequency, mean $=1.27 \pm 2.12$ ) and the boundary area (number of dens, mean $=0.34 \pm 0.53$; frequency, mean $=0.45 \pm 0.93$ ) of the home range. We discuss our results in terms of the importance of dens in facilitating escape from Coyotes. These results illustrate the need for examining den site selection at multiple scales to determine all selection factors, and to provide information useful for recovery and management efforts for this species.

Key Words: Swift Fox, Vulpes velox, denning, habitat selection, home range use, Colorado.

\section{Introduction}

The Swift Fox (Vulpes velox) is native to the short and mid-grass prairies of North America. The current range of the Swift Fox is much reduced from the historic range, and the species was formerly a candidate for endangered species listing (United States Fish and Wildlife Service 1996). The Swift Fox has been locally extirpated in the northern prairies in Canada, North Dakota, and much of South Dakota (Scott-Brown et al. 1987). One of the principal causes of Swift Fox population declines across much of the historical range is a reduction in suitable habitat (Hillman and Sharps 1978).

The combined availability and distribution of suitable den sites and escape holes is likely a habitat component for Swift Foxes (Egoscue 1979; Rongstad et al. 1989; Herrero et al. 1991). Swift Foxes were referred to as the "burrowing fox" by Lewis and Clark and are considered one of the most fossorial canids in North America because they use dens throughout the year (Kilgore 1969; Egoscue 1979). Swift Foxes spend the majority of diurnal hours in dens or near den entrances, often concurrently with a mate (Cutter 1958; Kitchen et al. 1999). Denning might enable Swift Foxes to maintain homeostasis by providing a cool, damp microhabitat refuge. Dens offer shelter from the elements and facilitate escape from predators, especially Coyotes (Canis latrans), in an environment that offers little natural cover (Egoscue 1979; Rongstad et al.1989; Herrero et al. 1991; Pruss 1999). Kitchen et al. (1999) found all Coyote-killed Swift Foxes near the periphery or outside their home range boundary, a significant distance from their nearest currently used den.

Thus, knowledge of habitat requirements for den sites might be an important component of Swift Fox conservation efforts (Hillman and Sharps 1978; Pruss 1999); however, results of studies on Swift Fox den site selection have varied. Swift Foxes may modify burrows dug by other animals such as American Badgers (Taxidea taxus), ground squirrels (Spermophilus spp.) or Black-tailed Prairie Dogs (Cynomys ludovicianus), or dig their own dens (Kilgore 1969; Hillman and Sharps 1978; Cameron 1984; Pruss 1999). Dens have been found in a variety of habitat types including shortand mid-grass prairie, grazed prairie, cultivated fields, fence rows, and rock outcrops (Cutter 1958; Hines 1980; Cameron 1984; Uresk and Sharps 1986; Rongstad et al. 1989; Pruss 1999). Occasionally, dens have been associated with man-made structures such as culverts, buildings, and cemetery gravesites with a concrete cap (Kilgore 1969; Hillman and Sharps 1978; Jackson and Choate 2000). Dens are frequently locat- 
ed on or near tops of gently sloping hills, which are well drained and have a clear line of sight (Hillman and Sharps 1978; Cameron 1984; Uresk and Sharps 1986; Pruss 1999; Harrison 2003). However, dens also have been found in level, open areas and the base of hills (Kilgore 1969; Hines 1980; Cameron 1984).

Den entrance characteristics vary among seasons and individual dens. There are indications that natal dens typically have more entrances than non-natal dens (Kilgore 1969; Hillman and Sharps 1978). Hines (1980) reported that Swift Foxes seem to select for entrances with west and east exposures. Similarly, Uresk and Sharps (1986) documented a trend toward dens with easterly exposures. In contrast, Rongstad et al. (1989) and Pruss (1999) found entrance exposure to be random.

An additional factor that might influence the selection of dens is the position of the site within the home range. Previous studies investigating den use in Swift Foxes have not considered den placement within the range as a factor influencing selection. We contend, however, that due to the importance of dens for predator escape (Herrero et al. 1991; Kitchen et al. 1999; Pruss 1999), placement relative to the home range core and boundary areas might be a driving force in selection. It is likely den placement is correlated to overall space use patterns and dens are positioned to facilitate a quick escape from an approaching predator.

The objective of this study was to determine the factors affecting den site selection for Swift Foxes on the Pinon Canyon Maneuver Site, in southeastern Colorado. We examined den site placement and microhabitat characteristics of active Swift Fox dens and compared these to sites not used by Swift Foxes.

\section{Methods}

Study Area

We conducted the study on the $1040-\mathrm{km}^{2}$ Pinon Canyon Maneuver Site (PCMS) in Las Animas County, Colorado. The dominant cover type on the PCMS is native grassland $(60 \%)$, with Juniper (Juniperus monosperma) and Pinyon Pine (Pinus edulis) communities found in the hills and canyons (Shaw et al. 1989). Annual precipitation ranges from 26 to $38 \mathrm{~cm}$ (United States Department of Army 1980). Mean monthly temperatures range from $-1^{\circ} \mathrm{C}$ in January to $23^{\circ} \mathrm{C}$ in July (Andersen and Rosenlund 1991). Predators known to kill Swift Fox are Coyotes (Covell 1992; Kitchen et al. 1999) and raptors (Covell and Rongstad 1990).

\section{Swift Fox Capture}

Swift Foxes were captured with double-door box traps $(80 \times 25 \times 25 \mathrm{~cm})$ baited with chicken or mackerel (Covell 1992). We deployed traps in the evening and checked them the following morning. Traps were not activated during periods when nighttime temperatures dropped below $-10^{\circ} \mathrm{C}$. We attached a radiocollar and ear tag to the Swift Fox and recorded the weight, sex and approximate age (using tooth wear) of the animal (Rongstad et al. 1989). All Swift Foxes were released at the site of capture. We followed telemetry procedures recommended by White and Garrott (1990). Locations were obtained by triangulating 2-3 bearings to the animal's position within a 10-minute period. Triangulation angles were maintained between $20^{\circ}$ and $160^{\circ}$ (Gese et al. 1988). We used aerial telemetry (Mech 1983 ) to locate missing animals. Telemetry error was determined by comparing telemetry locations with actual locations of stationary reference transmitters. When Swift Foxes were located in a den, we recorded the UTM coordinates of the den. We attempted to locate Swift Foxes approximately every 1-3 days with locations obtained throughout the $24-\mathrm{h}$ period to reduce bias in home range estimates (used for den placement analysis).

\section{Den Site Characteristics}

Microhabitat characteristics of den sites were measured at a randomly selected sub-sample of the known active dens used by Swift Foxes during the breeding season (defined on the basis of energetic demands due to climatic changes and prey abundance, and behavioral characteristics to be 15 December to 14 April). Active dens were found by tracking radio-collared Swift Foxes. Den site selection was not stratified by sex as Swift Foxes form pair bonds with males and females concurrently using the same dens.

The following physical characteristics were measured at each den site: number of entrances, height and width of each entrance, den aspect, den position on hills, slope of site, percent rock in soil, vegetative cover, and horizontal foliar density. These characteristics were selected based on field observations and published descriptions of potentially important habitat characteristics (Hines 1980; Cameron 1984; Ursek and Sharps 1986; Rongstad et al. 1989; Covell 1992; Pruss 1999).

Den position on a hill was classified as bottom, middle, top, or flat when there was no hill. We determined maximum slope outside the den using a hand-held clinometer (Hays et al. 1981). The percentage of rock in the soil was visually estimated from the presence of rock in the dirt mound runway leading to the den entrance. Vegetation cover was determined by estimating the percent cover of grasses, forbs, shrubs, and bare soil in eight $1-\mathrm{m}^{2}$ plots randomly located within $10 \mathrm{~m}$ of the den. Percent soil and vegetation cover were estimated within the nearest $5 \%$ category. We indexed horizontal foliar density at 5 distances $(10,20,30,40$, and $50 \mathrm{~m}$ ) from the den in the four cardinal directions with a vegetation profile board and techniques for the fixed distance approach (Hays et al. 1981). The number of squares visible on a vertical board was counted by an observer lying down to approximate the visibility from the height of a Swift Fox. 

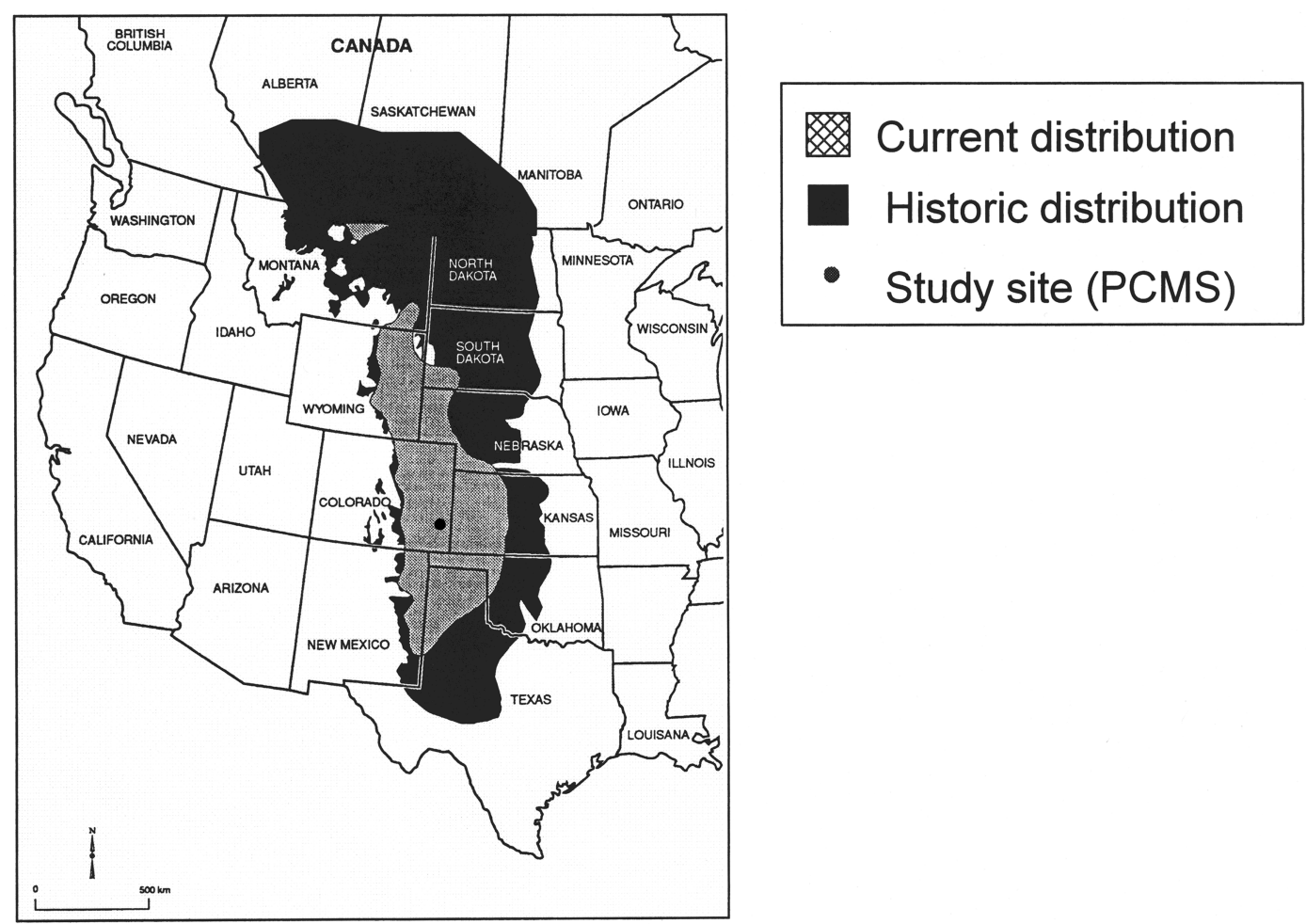

FiguRE 1. Swift Fox current and historic range and study area, Pinon Canyon Maneuver Site, Colorado, 2000.

\section{Den Site Selection}

To examine den site selection, we compared microhabitat characteristics of dens to control sites that represented available sites (Taylor et al. 1999). For each of the active den sites, we randomly selected one control site (not a den) within the Swift Foxes home range. We used the control site to compare the site characteristics of active den sites versus random sites within the Swift Foxes' home range. The control site was located $500 \mathrm{~m}$ away from the active den site in a random direction. This distance was arbitrary but allowed for selection of a random location within the home range. Because control sites were in the home range of the Swift Fox inhabiting the active den site, they were considered available as a possible denning location to the Swift Fox. The same den site characteristics were evaluated on the control sites, excluding variables associated with den entrances.

\section{Den Placement}

Dens used by Swift Foxes during the breeding season were recorded using telemetry procedures to assess the placement and use of the dens within the home range. The Swift Foxes' home ranges were described using a $95 \%$ fixed kernel home-range estimator based on $>30$ locations recorded within the breeding sea- son (Worton 1989) with Arcview 3.0 software (Environmental Systems Research Institute, Inc., Redlands, California). Areas within the home range were then defined as the core area, which was the area within the $50 \%$ isopleth, the mid-range area, between the 50\% and $75 \%$ isopleths, and the boundary area, between the $75 \%$ and the $95 \%$ isopleths. The number of dens and the frequency of use of those dens in the core, midrange, and boundary areas of the home range were compared. In addition, we compared the number of dens in each area to the number expected from the proportion of each area in the home range; i.e., $50 \%$ within the core area, $25 \%$ within the mid-range area, and $20 \%$ within the boundary area.

\section{Statistical Analysis}

Because the habitat measurements were categorical, chi-square tests were used to assess the difference between habitat characteristics at active dens versus control sites (Zar 1999). Whether den entrances were randomly distributed around a circle (i.e., no predominant direction) was tested using Rayleigh's nonparametric $\mathrm{Z}$ test (Zar 1999). We attempted to predict class membership (i.e., active dens or control sites) by using a classification tree analysis with cost complexity pruning (CART: Verbyla 1987; S-Plus Version 6.0 1988- 
2001.). Also called tree regression (Rejwan et al. 1999), this method repeatedly partitions the study sites into two groups (active dens and control sites) that are as similar as possible based upon the five variables common to both groups (position, slope, horizontal foliar density, percent rock in soil, and percent vegetative cover). Each of the independent variables is used at each step in the analysis regardless of whether they were previously used in the tree. The tree that is created is hierarchically structured with the complete data set at the top (the root) and the binary splits, referred to as "nodes", below to the final undivided "leaves" or groupings at the bottom of the tree. Analysis of variance with Tukey-adjusted post-hoc comparisons was used to assess the difference in the number of dens used and the number of times these dens were used by area (SAS Version 8.2 2001). Log transformations were used to achieve normality where deviations occurred. In cases where more than one den per Swift Fox was sampled, one den was randomly chosen for analysis to avoid pseudoreplication.

\section{Results}

Forty-two dens belonging to 42 Swift Foxes were located from December 1999 to April 2000 and used to evaluate den site characteristics. Most active dens had only one or two entrances and the maximum number of den entrances was seven. The mean height of den entrances was $19.4 \pm 3.1 \mathrm{~cm}$ and the mean entrance width was $17.9 \pm 2.5 \mathrm{~cm}$. The percentage of dens with entrances oriented to the north, south, east, and west were $29.9,21.1,21.9$, and $27.1 \%$, respectively. These aspects were randomly distributed around a circle $\left(Z_{41}=0.088 ; P=0.54\right)$, i.e., dens were not oriented in a predominant direction.

The mean maximum slope of active dens was $1.3 \pm$ 1.3 degrees. We found no difference between the slope at den sites and control sites $\left(\chi^{2}=2.71, \mathrm{df}=4\right.$, $P=0.61)$. Most dens $(88.7 \%)$ and control sites $(80.3 \%)$ were located on gentle slopes between 0 and 2 degrees. Four percent of control sites were located on slopes that exceeded 5 degrees, however, no dens were found on slopes that steep. The majority of Swift Fox dens were positioned either on flat ground or in the middle of a hill, and relatively few dens were located at the top or bottom of a hill (Figure 1). Control sites were found in similar positions with no detected difference between site position of used and control sites $\left(\chi^{2}=2.04, \mathrm{df}=3\right.$, $P=0.59$; Figure 1). We also found no difference in the pattern of visibility by distance from the den as compared to control sites $\left(\chi^{2}=0.06\right.$, df $\left.=4, P=0.99\right)$. Visibility from both active den sites and control sites decreased uniformly in each direction as one moved away from the site. The vegetative cover of den sites and control dens was similar $\left(\chi^{2}=1.98, \mathrm{df}=3\right.$, $P=0.598)$ with both dens and control sites occurring in areas mostly covered in grasses and soil (Figure 2). There was a significant difference in the percentage of rock at dens versus control sites $\left(\chi^{2}=8.91, \mathrm{df}=3\right.$, $P=0.03$; Figure 3) with dens having higher proportions of intermediate percentages of rock and control sites having higher proportions of rock below $5 \%$ or above $20 \%$. The classification tree used to characterize the habitat at dens versus control sites failed to produce any biologically relevant pattern.

The average number of dens used per Swift Fox during the breeding season was $5.1 \pm 2.1$. The number of dens used by Swift Foxes varied by area of the home range $\left(F_{2,33}=37.53, P<0.001\right.$; Figure $\left.4 a\right)$. Tukey's adjusted post-hoc tests indicated that more dens were used in the core area than in the mid-range and boundary areas (mid-range: $t_{33}=6.29, P<0.001$; boundary: $t_{33}=-7.54, P<0.001$ ). There were also significantly more dens in the mid-range area than the boundary area $\left(t_{33}=-2.20, P=0.035\right)$. In addition, we found that the number of dens in each area varied from that expected from the proportion of the area, and thus the frequency of use of the area $\left(\chi^{2}=38.41\right.$, $\mathrm{df}=3, P<0.0001)$.

Overall, there was a difference in the frequency of use of dens in the different areas of the home range $\left(F_{2,33}=44.94, P<0.001 ;\right.$ Figure $\left.4 \mathrm{~b}\right)$. The number of

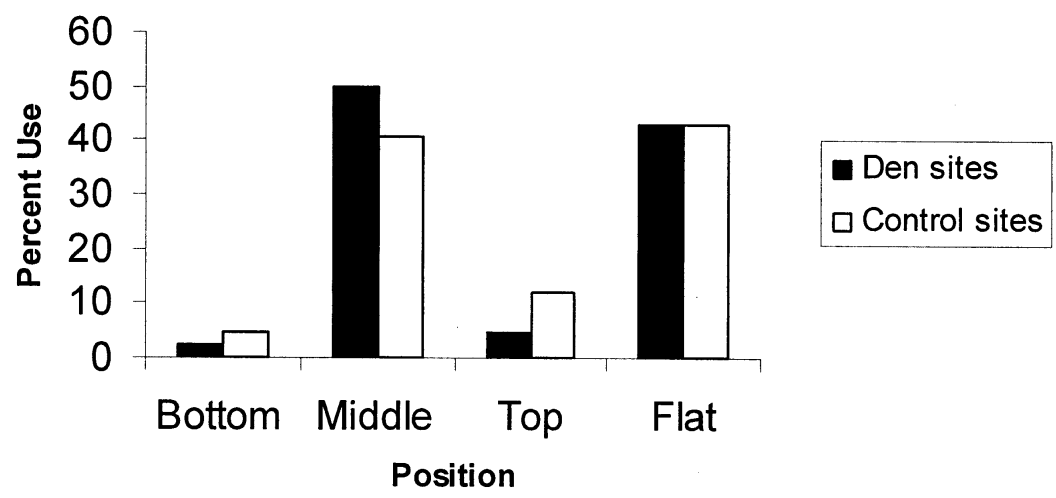

FIgURe 2. Position of Swift Fox den sites and control sites, Pinon Canyon Maneuver Site, Colorado, 2000. 


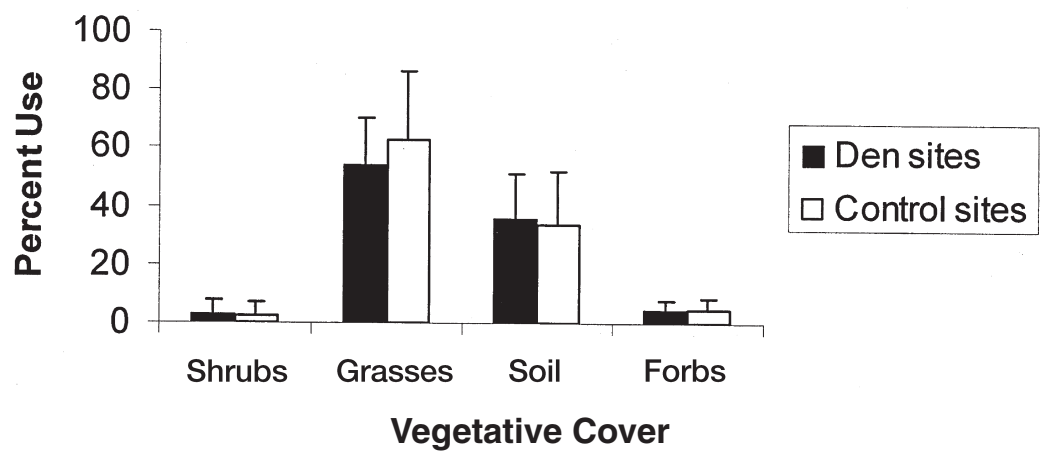

FIgURE 3. Vegetative cover at Swift Fox den sites and control sites, Pinon Canyon Maneuver Site, Colorado, 2000.

times that dens in the core area were used was higher than in the mid-range or boundary areas (mid-range: $t_{33}=7.52, P<0.001$; boundary: $t_{33}=7.65, P<0.001$ ). There was no difference in the number of times dens in the mid-range and boundary areas were used $\left(t_{33}=1.55\right.$, $P=0.13)$. The pattern of den use was variable. For example, one Swift Fox was located in only one den for a period spanning 67 days, while another Swift Fox used at least four different dens in a five-day period.

\section{Discussion}

Our results indicated Swift Foxes on the PCMS did not select den sites based on the microhabitat characteristics that we evaluated. However, Swift Foxes appeared to select areas of intermediate rock percentages. The selection of areas with intermediate rock percentages may be related to den structure and strength. Foxes had no preference for particular positions or vegetation at den sites despite other studies concluding that
Swift Foxes preferentially selected den sites on hilltops (Uresk and Sharps 1986; Pruss 1999; Harrison 2003).

The finding that Swift Foxes in our study area select den sites with habitat characteristics that do not differ from control sites was not unexpected considering the homogeneous prairie environment on the PCMS. Our result does differ from other Swift Fox studies which reported preferences for certain habitat characteristics, however. The importance of selection of hill position and vegetation characteristics might be determined by variation in topography and habitat in the geographic area. Habitat selection by Swift Foxes on the PCMS appears to operate at the landscape level instead of at the den site level as Swift Foxes were only trapped on the open prairie on the PCMS despite efforts to capture Swift Foxes in wooded areas (Schauster et al. 2002).

Den site selection occurred at a larger scale; the placement of dens relative to areas within the home range was a significant factor in site selection. Foxes

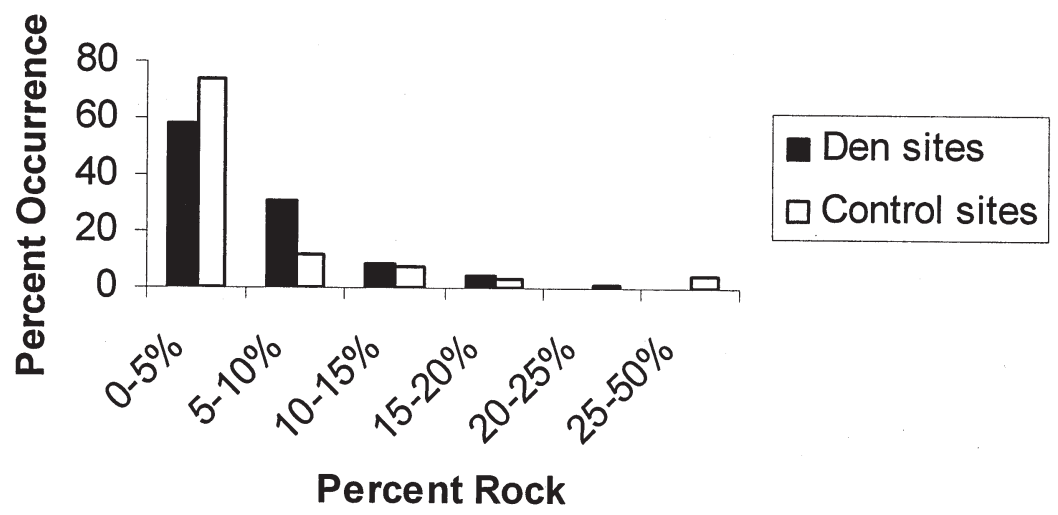

Figure 4. Percentage of rock at Swift Fox den sites and control sites, Pinon Canyon Maneuver Site, Colorado, 2000. 

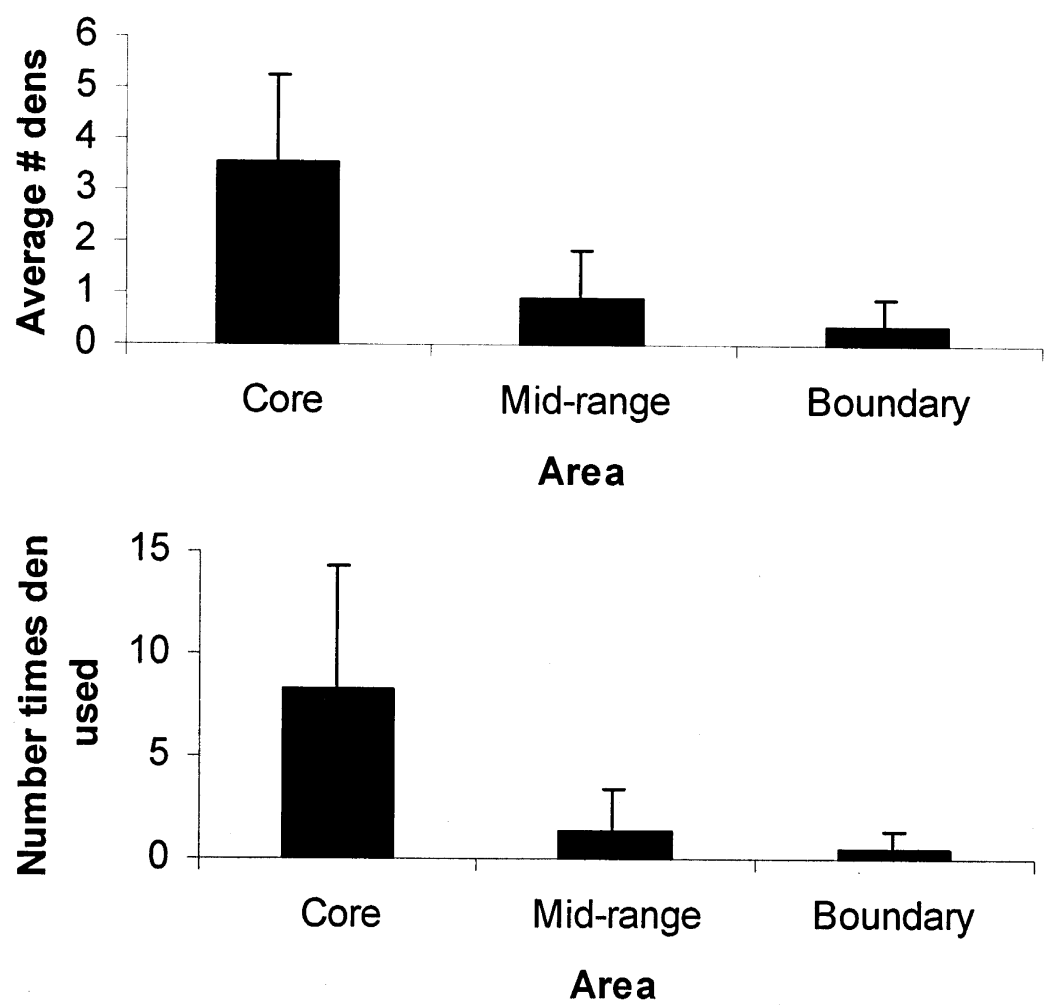

FIGURE 5. Placement of Swift Fox dens within the home range (top) and frequency of Swift Fox den use by area of the home range (bottom), Pinon Canyon Maneuver Site, Colorado, 2000.

used more dens in the core area of the home range as compared to the mid-range or boundary areas. In addition, dens in the core area were used more frequently by radio-tracked Swift Foxes than dens in the midrange or boundary area. Den placement within the home range may be designed to facilitate escape from Coyotes. Previous studies have indicated that Swift Foxes use dens as a mechanism of escape from predators (Herrero et al. 1991; Kitchen et al. 1999; Pruss 1999) and that Coyote-caused mortality might be a key factor in limiting population growth in North America as well as the re-establishment of Swift Foxes on the Canadian prairies (Scott-Brown et al. 1987). Kitchen et al. (1999) found that all Coyote-caused Swift Fox mortalities occurred near or outside the Swift Fox's home range boundary, a substantial distance from their nearest currently used den.

Thus, Swift Foxes might maintain the majority of dens in the core area of the home range where they spend most of their diurnal hours (Schauster et al. 2002), and use dens only occasionally in the outer areas of their range to reduce encounters with and facilitate escape from predators. Previous studies have suggested that other preferences for den sites also might be due to Coyote avoidance, including den locations that are negatively associated with water sources (Pruss 1999), and dens that are closer to roads than unoccupied sites (Pruss 1994; Harrison 2003).

The importance of interspecific competition in determining den site selection has also been noted in Kit Foxes (List and Macdonald 2003) and Arctic Foxes (Alopex lagopus; Frafjord 2003). Frafjord (2003) documented that the distance to Red Fox (Vulpes vulpes) dens and the elevation from the tree line were the most important factors determining den use in Arctic Foxes. Kit Foxes in Mexico denned more often in grasslands and less in Prairie Dog (Cynomys ludovicianus) towns than expected (List and Macdonald 2003). These authors hypothesized that Kit Foxes reduced the amount of time they spent in Prairie Dog towns due to the activity of Coyotes.

Thus, Swift Fox den site selection in homogenous environments might be unrelated to microhabitat characteristics and more dependent on interspecific interactions and predator avoidance. This study also illustrates the importance of examining den site selection at multiple scales to determine all site selection factors. Due to the importance of denning to Swift Fox 
ecology, a full understanding of den site selection in various environments is essential to recovery, reintroduction, and management efforts.

\section{Acknowledgments}

Funding and assistance provided by the U.S. Army, Directorate of Environmental Compliance and Management (DECAM), Fort Carson, Colorado, through the U.S. Fish and Wildlife Service (USFWS), Colorado Fish and Wildlife Assistance Office, Golden, Colorado, and the Utah Cooperative Fish and Wildlife Research Unit at Utah State University, Logan, Utah. Additional support provided by the U.S. Department of Agriculture, Wildlife Services, National Wildlife Research Center, Logan Field Station at Utah State University, Logan, Utah. We thank T. Warren, G. Belew, and R. Bunn at DECAM, and B. Rosenlund at the USFWS for logistical support. We thank E. Bergman, E. Joyce, S. Karki, M. Klavetter, A. Kozlowski, H. Kratz, and L. Schutte for field assistance. Research protocols were approved by the Institutional Animal Care and Use Committees (IACUC) at the National Wildlife Research Center and Utah State University.

\section{Literature Cited}

Andersen, D. E., and B. D. Rosenlund. 1991. Fish and wildlife management recommendations: Pinon Canyon Maneuver Site, Las Animas County, Colorado. 1-84. United States Fish and Wildlife Service, Golden, Colorado, USA.

Cameron, M. W. 1984. The Swift Fox (Vulpes velox) on the Pawnee National Grassland: its food habits, population dynamics and ecology. Unpublished MS thesis, University of Northern Colorado, Greeley, Colorado.

Covell, D. F. 1992. Ecology of the Swift Fox (Vulpes velox) in southeastern Colorado. M.S. thesis, University of Wisconsin, Madison, Wisconsin.

Covell, D. F., and O. J. Rongstad. 1990. Ecology of swift fox on the Pinon Canyon Maneuver Site. Annual Report to Fort Carson, Colorado.

Cutter, W. L. 1958. Denning of the Swift Fox in Northern Texas. Journal of Mammalogy 39: 70-74.

Egoscue, H. G. 1979. Vulpes velox. Mammalian Species 122: 1-5.

Frafjord, K. 2003. Ecology and use of arctic fox Alopex lagopus dens in Norway: tradition overtaken by interspecific competition? Biological Conservation 111: 445-453.

Gese, E. M. 1998. Response of neighboring Coyotes (Canis latrans) to social disruption in an adjacent pack. Canadian Journal of Zoology 76: 1960-1963.

Gese, E. M., O. J. Rongstad, and W. R. Mytton. 1988. Home-range and habitat use of coyotes in southeastern Colorado. Journal of Wildlife Management 52: 640-646.

Harrison, R. 2003. Swift Fox demography, movements, denning, and diet in New Mexico. Southwestern Naturalist 48: 261-273.

Hays, R. L., C. Summers, and W. Seitz. 1981. Estimating wildlife habitat variables. U.S.D.I. Fish and Wildlife Service. FWS/OBS-81/47.

Herrero, S., C. Mamo, L. Carbyn, and M. Scott-Brown. 1991. Swift Fox reintroduction into Canada. Provincial Museum of Alberta. Natural History Occasional Paper Number 15.
Hillman, C. N., and J. C. Sharps. 1978. Return of Swift Fox to northern Great Plains. Proceedings of the South Dakota Academy of Science 57: 154-162.

Hines, T. D. 1980. Home range and movements of Swift Fox (Vulpes velox) as determined by radio telemetry. Proceedings of the Nebraska Academy of Science 90: 7.

Jackson, V. L., and J. R. Choate. 2000. Dens and den sites of the Swift Fox, Vulpes velox. Southwestern Naturalist 45: 212-220.

Kilgore, D. L. 1969. An ecological study of the Swift Fox (Vulpes velox) in the Oklahoma Panhandle. American Midland Naturalist 81: 512-533.

Kitchen, A. M., E. M. Gese, and E. R. Schauster. 1999. Resource partitioning between Coyotes and Swift Foxes: space, time, and diet. Canadian Journal of Zoology 77: 1645-1656.

List, R., and D. W. Macdonald. 2003. Home range and habitat use of the kit fox (Vulpes macrotis) in a prairie dog (Cynomys ludovicianus) complex. Journal of Zoology 259: 1-5.

Mech, L. D. 1983. Handbook of animal radiotracking. University of Minnesota Press, Minneapolis.

Pruss, S. D. 1994. An observational natal den study of wild Swift Fox (Vulpes velox) on the Canadian Prairies. Unpublished Master's of Environmental Design thesis. University of Calgary, Alberta.

Pruss, S. D. 1999. Selection of natal dens by the Swift Fox (Vulpes velox) on the Canadian prairies. Canadian Journal of Zoology 77: 646-652.

Rejwan, C., N. C. Collins, L. J. Brunner, B. J. Shuter, and M.S. Ridgway. 1999. Tree regression analysis on the nesting habitat of smallmouth bass. Ecology 80: 341-348.

Rongstad, O. J., T. R. Laurion, and D. E. Andersen. 1989. Ecology of Swift Fox on the Pinon Canyon Maneuver Site, Colorado. Final Report, DECAM, Ft. Carson, Colorado.

S-Plus Version 6.0. 1988-2001. Insightful Corporation, New York, New York.

SAS Version 8.2. 2001. SAS Institute, Cary, North Carolina.

Schauster, E. R., E. M. Gese, and A. M. Kitchen. 2002. Population ecology of Swift Foxes (Vulpes velox) in southeastern Colorado. Canadian Journal of Zoology 80: 307319.

Scott-Brown, J. M., S. Herrero, and J. Reynolds. 1987. Swift Fox. Pages 432-441 in Wild furbearer management and conservation in North America. Edited by M. Novak, J. A. Baker, M. E. Obbard, and B. Malloch. Ontario Ministry of Natural Resources, Toronto.

Shaw, R. B., S. L. Anderson, K. A. Schulz, and V. E. Diersing. 1989. Plant communities, ecological checklist, and species list for the U.S. Army Pinon Canyon Maneuver Site, Colorado. Colorado State University. Science Series 37.

Taylor, J. S., K. E. Church, and D. H. Rusch. 1999. Microhabitat selection by nesting and brood-rearing northern bobwhite in Kansas. Journal of Wildlife Management 63: 686-694.

United States Department of Army. 1980. Draft: environmental impact statement for acquisition of training land in Huerfano, Las Animas and Pueblo counties, Colorado. United States Department of Army, Fort Carson, Colorado.

United States Fish and Wildlife Service. 1996. Endangered and threatened wildlife and plants; review of plant and animal taxa that are candidates for listing as endangered or threatened species. Federal Register 61: 7596-7613. 
Uresk, D. W., and J. C. Sharps. 1986. Denning habitat and diet of the Swift Fox in western South Dakota. Great Basin Naturalist 46: 249-253.

Verbyla, D. L. 1987. Classification trees: a new discrimination tool. Canadian Journal of Forest Resources 17: 11501152.

White, G. C., and R. A. Garrott. 1990. Analysis of radiotracking data. Academic Press, New York, New York.
Worton, B. J. 1989. Kernel methods for estimating the utilization distribution in home range studies. Ecology 70 : 164-168.

Zar, J. H. 1999. Biostatistical analysis. Prentice-Hall, Inc. New Jersey.

Received 8 December 2004

Accepted 15 November 2006 